\title{
On Stuff
}

\section{Clare Pettitt}

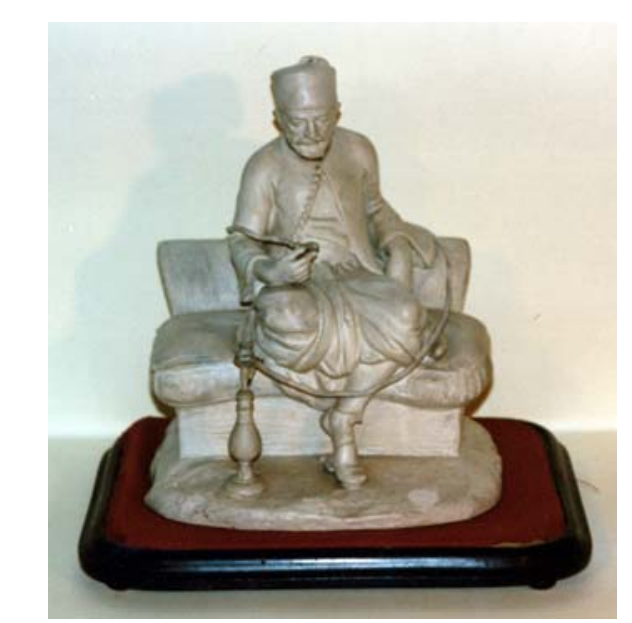

Courtesy of the Charles Dickens Museum, London. www.dickensmuseum.com
At his beloved house at Gad's Hill Place in Kent, Dickens kept a small sculpture of a smoking Turk sitting upon his desk, and a small porcelain monkey too. He must have looked at them almost every day, fingered them, glared at them perhaps when the words weren't flowing as well as usual. He is said to have been fond of them. Quite what they meant to him and what his affective relationship to them might now mean to us is a

question which - if taken properly seriously - plunges us into a profound encounter with the object world - with the plethora of things that make up our daily habitudes. How we ask things 'to make meaning, to remake ourselves, to organize our anxieties and affections, and to sublimate our fears and shape our fantasies' is one of Bill Brown's fundamental questions in his A Sense of Things (2003). ${ }^{1}$ The monkey and the smoking Turk are now in the Charles Dickens Museum at number 48 Doughty Street, London, in the house in which Dickens lived with his new wife from 1837 to 1839 . It was here that he finished Pickwick Papers (1836-7) and Oliver Twist (1837-9), wrote Nicholas Nickleby (1838-9), began work on Barnaby Rudge (1841) and became a success.

The Dickens House Museum displays cutlery, teacups, snuffboxes, walking sticks and pens that belonged to Dickens: even a fragment of the curtains that were hanging in his library at Gad's Hill until his death is framed on the wall, and on the whole Dickens's things seem to be unremarkable examples of bourgeois Victorian taste. But the museum has also become a sanctuary for some of the street furniture of the nineteenth century that appeared in Dickens's novels - on the first-floor landing of Doughty Street

\section{Claire Pettitt, On Stuff}

19: Interdisciplinary Studies in the Long Nineteenth Century, 6 (2008) www.19.bbk.ac.uk 
is the original of the little wooden midshipman with his 'attitude of indomitable alacrity' that stands outside Sol Gills's nautical instruments shop in Dombey and Son (1846-8). ${ }^{2}$ Dickens saw the figure on Leadenhall Street outside Messrs. Imray, Laurie, Norie, and Wilson Ltd., Chart Publishers, and it jumped straight into his book. Now the company has lent it indefinitely to the museum. Even more surreal, protruding from the wall on the half-landing is a disembodied gold arm wielding a hammer. The labelling records this as the 'Coalbeater's Arm' which was taken from No. 2 Manette Street, Soho and is the original of the 'mysterious giant

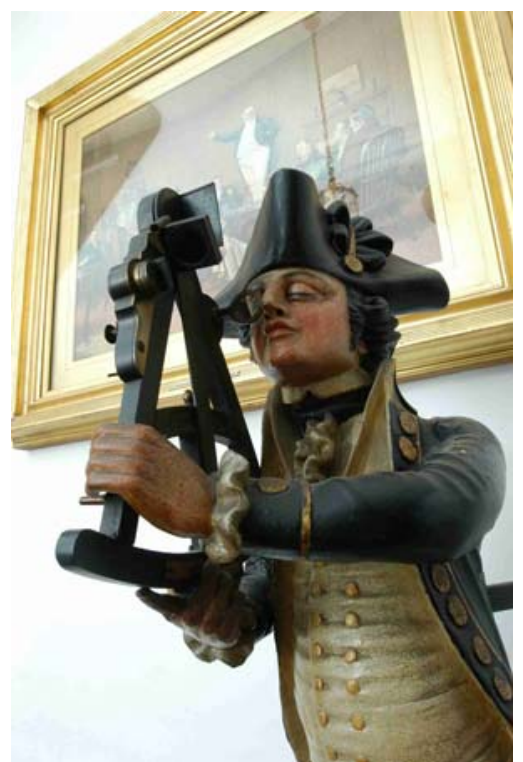

Courtesy of the Charles Dickens

Museum, London.

www.dickensmuseum.com who had a golden arm starting out of the wall as if he had beaten himself precious, menaced a similar conversion of all visitors' near Dr. Manette's lodgings 'in a quiet street corner not far from Soho' in A Tale of Two Cities (1859). ${ }^{3}$

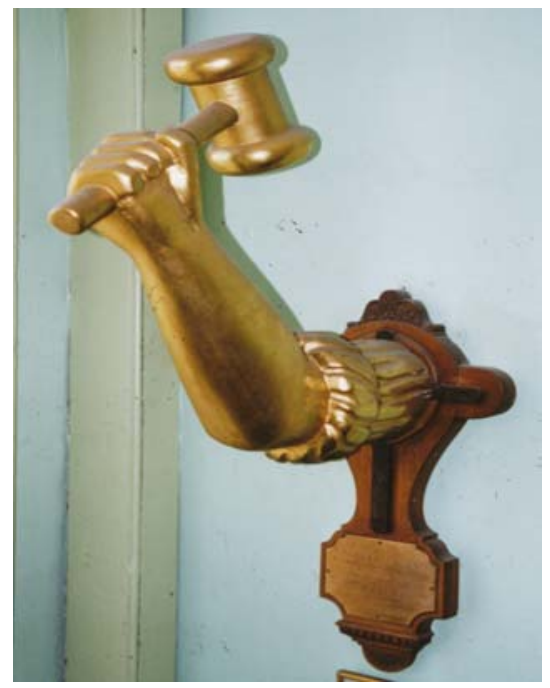

Courtesy of the Charles Dickens Museum, London. www.dickensmuseum.com
There is something faintly alarming in the posthumous invasion of Dickens's domestic space by these street signs. What is exactly the connection between the ingenious lemon squeezer that we are told was 'used by Charles Dickens at Gad's Hill Place and given to him by his doctor A.T.V. Packham' and that surreal golden arm? ${ }^{4}$ One can - just about - imagine Dickens enjoying squeezing lemons into a punch, perhaps, and remembering his friend, the doctor, affectionately as he turned the screw-mechanism.

But the midshipman and the arm were never part of Dickens's domestic scene: they 
became part of the 'stuff' of his imagination, but he never owned or touched them. In Dombey and Son Walter seems fond of the midshipman whom he eyes 'kindly [...] in passing in and out' of the shop, and Old Sol regards the figurine as 'the guardian genius of his trade' but Dickens insists on the thing-like obduracy of the wooden figurine: 'no fierce idol with a mouth from ear to ear, and a murderous visage made of parrot's feathers, was ever more indifferent to the appeals of its savage votaries, than was the Midshipman to these marks of attachment' (DS 287). The wooden midshipman and the 'menacing' golden arm both repel affection. They seem out of place in this private house partly because they are advertisements, and as such they seem out of place in exactly the way that Bill Brown describes the 'gigantic golden molar of French gilt' which starts life as a shop sign in Frank Norris's novel, McTeague (written 1895, published 1899), but after McTeague's failure as a dentist becomes a table piled with 'plates and greasy dishes.' Brown comments that 'When you use a tooth as a table, it becomes a table,' citing it as an example of the fungibility of objects in Norris's novel. ${ }^{5}$

But the midshipman and the giant arm are also out of place because they are imaginary things, not 'real' things. It turns out that they are, in fact, 'real' things, but that does not alter their primary ontological status as imaginary. They are things that have been dematerialized in Dickens's novels and their rematerialization in his house labelled as 'originals' must surely force questions about the process of the creative imagination. Dickens's lemon squeezer is exceptional because it was Dickens's - its very banality as an object paradoxically reinforces the exceptionality of its history, but these two advertisements are exceptional only because they fell into the trawling net of Dickens's imagination as he walked the London streets. Here is a difference between the affect stored in an object owned and used, and in objects seen, re-imagined and represented in literature.

But perhaps the best example of this uneasy cohabitation of things at Doughty Street is the grill of wooden bars from the Marshalsea Prison, Southwark, which is mounted on a wall in the basement - with photographs of Dickens's parents trapped on the wall

19: Interdisciplinary Studies in the Long Nineteenth Century, 6 (2008) www.19.bbk.ac.uk 
behind it. Of course, Dickens's family were famously incarcerated for debt in the prison in 1824, and the twelve-year-old Dickens was sent to suffer and work at Warren's Blacking Warehouse down by the river for 6 shillings a week.

Courtesy of the Charles Dickens Museum, London. www.dickensmuseum.com

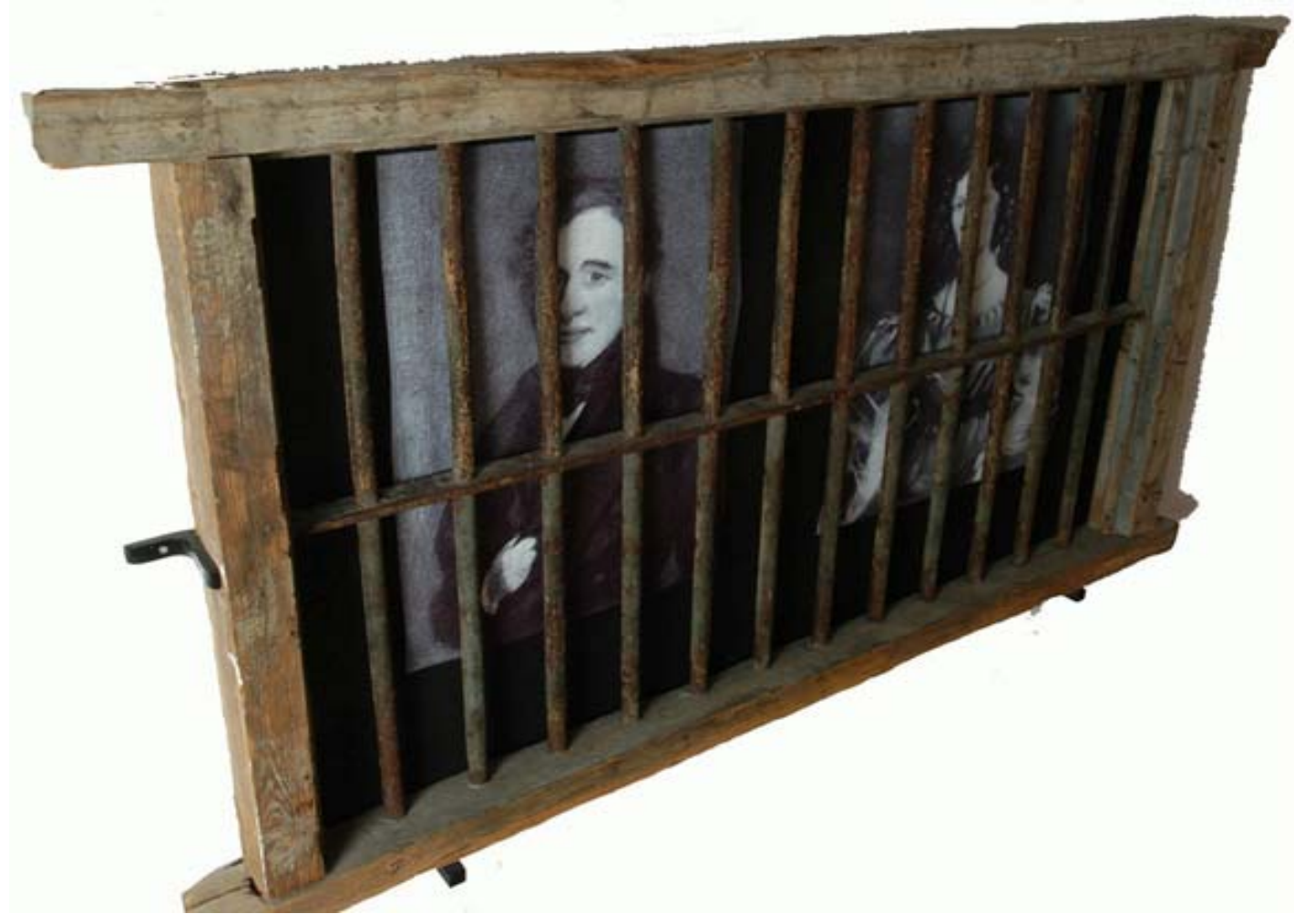

It was an episode that he kept secret all his life - the first that anyone, including his children, knew about it was when John Forster published some fragments of Dickens's autobiography in the first volume of his biography of his friend in 1876. If the tea cups and monogrammed cutlery are there to summon up a sense of Dickens's own bodily mass, to bear the imprint of his hands, his lips, his lemons, then the presence of the prison grill from Southwark creates an effect rather like one of Pip’s disturbed dreams in Great Expectations (1860-1): 'All night there were coaches in my broken sleep, going to wrong places instead of to London, and having in the traces, now dogs, now cats, now pigs, now men - never horses. ${ }^{6}$ Here the Marshalsea Prison is very much in

\section{Claire Pettitt, On Stuff}

19: Interdisciplinary Studies in the Long Nineteenth Century, 6 (2008) www.19.bbk.ac.uk 
the wrong place: lurking outside Dickens's kitchen. The presence of this striking object in the basement corridor of the house in which the young Dickens family clattered and chatted and dined and sang provides an 'object lesson' in the possibilities of some things to displace and challenge other things. Or, in other words, it suggests that affect and history is 'stockpiled' in things to use Elaine Freedgood's helpful expression from her The Ideas in Things: Fugitive Meaning in the Victorian Novel (2006), and things as we all know really - can disburse themselves of their meanings in unexpected and sometimes devastating ways. ${ }^{7}$ Jean Baudrillard has declared that 'we have always lived off the splendor of the subject and the poverty of the object' and in a museum such as Dickens House, where things are expected to behave themselves and to evoke the splendour of Dickens as a subject, it is weird how much those very same things when set against each other seem rather to assert themselves and their own competing histories. $^{8}$

This is close, but not identical to Freedgood's central argument in her eminently readable and thought-provoking book, The Ideas in Things. The knowledge 'stockpiled' in things, Freedgood argues, 'bears on the grisly specifics of conflicts and conquests that a culture can neither regularly acknowledge nor permanently destroy if it is going to be able to count on its own history to know itself and realize a future' ${ }^{9}$ In a series of four chapters she enumerates three 'things': mahogany furniture in Charlotte Brontë's Jane Eyre (1847), calico curtains in Elizabeth Gaskell's Mary Barton (1848), and 'Negro head' tobacco in Charles Dickens's Great Expectations. The fourth chapter offers a close reading of George Eliot's Middlemarch (1870-1) showing how the novel's narrator is intent on preventing the dangers that inhere in misinterpreting objects [...]. An early forecloser of metonymic plenitude, the narrator of Middlemarch is among our first metacritics of the material, our first guides to the correct process for assigning ideas to the things of fiction. ${ }^{10}$ Freedgood's book ends with a Coda which posits a model of 'Victorian Thing Culture' as an alternative to the consumer culture of commodities that has mesmerized cultural and literary critics of the nineteenth century for so long. As she elucidates earlier, Thing Culture is 'a more extravagant form of 
object relations than ours, one in which systems of value were not quarantined from one another and ideas of interest and meaning were perhaps far less restricted than they are for us.' 11

Freedgood is more interested in what things bring with them into the texts than what meanings the text assigns to them. Indeed, she is trying to 'avoid the temptations of allegory' and to unleash the full metonymic potential of the unregarded objects that clutter realist fiction: 'an interpretative open end of dizzying potential. ${ }^{12}$ She here attempts a 'strong' reading of these interpretative possibilities, 'metonymy has understandably been read, when read at all, weakly. ${ }^{13}$ Freedgood is an excellent reader and she provides exquisitely thoughtful and agile readings of all her main exampletexts. In the introduction, she speaks of ' $[t]$ he reader who wishes to recover (or rather, imagine) the material qualities of fictional things' - methodologically the gap between recovering and imagining poses a challenge to every historical endeavour, from archaeology to geology to literary studies - and the recovery of feelings, perceptions and the experience of touch and use must always rest largely upon the imagination. ${ }^{14}$ How far it is ever possible to imagine inhabiting history from the inside is partly what this book is about.

It is to the imperial and industrial histories of things that Freedgood's readings are most attracted. In chapter one, Freedgood excavates some of the 'back story' of the production of mahogany and suggests that in Jane Eyre mahogany furniture functions as a 'souvenir of sadism.' ${ }^{15}$ She explains it thus:

I am trying to make the furniture of Jane Eyre into what Marx would call a 'social hieroglyphic': to treat it as a complex and partly legible sign, to help us get 'behind the secret of our own social products.' The fact that furniture is not generally interpreted in all its woody splendor means that it can do lots of unapprehended symbolic work in the novel. An apparently innocent object like a mahogany dresser or a walnut panel decorates the moral and moralized space of the novel's winners, while sneaking in the true extent of their morally precarious triumph and evoking useful and self-protective memories of imperial mastery. Britons knew where their wood was coming from, especially that tropical treasure, mahogany. Even the slightest end

Claire Pettitt, On Stuff

19: Interdisciplinary Studies in the Long Nineteenth Century, 6 (2008) www.19.bbk.ac.uk 
table, the most unassuming side chair, could be a souvenir of sadism for Victorian readers of the novel. ${ }^{16}$

But in 1851 Henry Mayhew detailed the furnishings of a costermonger's cellar in London: 'All the chairs, which were old fashioned mahogany ones, had sound backs and bottoms' he wrote. ${ }^{17}$ What happens, one is left wondering, to the 'memories of imperial mastery' when the mahogany furniture no longer belongs to the 'winners'? Freedgood's reading of mahogany is perhaps too global and long-range. In the lowdown thick of the domestic economy of British working-class communities in the nineteenth century things as well as people were subject to sudden falls in status. The second-hand market not only cheapened mahogany furniture, but also distributed it liberally across classes. The very ubiquity of mahogany chairs must surely have made it difficult for Victorians to see each and every one as a 'souvenir of sadism'.

Carolyn Steedman, in her essay 'What a rag rug means', thinks about a misremembered rag rug that isn't actually there in chapter two of Mary Barton. ${ }^{18}$ Freedgood picks something which is actually there - the 'blue-and-white check curtains' in the Bartons' house in its comfortable days, during the 'good times among the mills' of Manchester. Steedman examines the absence of the rag rug in terms of the local economy speculating about this particular moment in the history of the factory working classes in Manchester, and about the value of rags to paper-making in

an economy in which such a tiny number of things circulated again and again, among so many people; where scarcity and technological under development created a shortage, not of the poor, but of the traditional symbols of the poor, their rags; and where even a handful of tattered clothing was worth a trip to the rag merchant, reckoned as it was until the late nineteenth century, as half a loaf of bread. ${ }^{19}$

But in the second chapter of her book, Freedgood offers a more global reading of the same novel - linking the checked curtains to world cotton markets and the association of checked fabric with the African-Caribbean slave trade and, in turn, the association of the slave trade with Indian calico. This chapter works well partly because cotton did, in a way that wood perhaps did not, generate a certain global romance at the time. Cotton

\section{Claire Pettitt, On Stuff}

19: Interdisciplinary Studies in the Long Nineteenth Century, 6 (2008) www.19.bbk.ac.uk 
also had much stronger and more frequently rehearsed contemporary associations with slavery and Freedgood's argument makes good sense. The third chapter which focuses on the 'Negro head' tobacco in Great Expectations as a literal evocation of the genocide of Aborigines in Australia seems more of a stretch. The fourth chapter on Middlemarch is adventurous and original in thinking through the ways in which Eliot self-consciously determines and limits the meaning of 'things' in her novel, and moves the argument firmly into narrative theory, and towards a new way of reading. Freedgood's book is compelling, witty and polemical and it sets up the debates brilliantly. It is elegantly short: a real achievement of concision as it is by no means a simple book. There are many things it does not claim to do, but what it does is intervene forcefully in the move to reassess the post-Marxist readings of 'commodity culture', enormously exciting as they were, (and still are in some cases), but which now threaten to stop us seeing nineteenth-century things for what they were.

Bill Brown in A Sense of Things is engaged with a time and place of even greater fecundity in terms of things - the 1880s and 1890s in America. Like Freedgood, he works through a series of close readings of particular literary texts, but while her focus was the realist British fiction of the middle years of the nineteenth century, Brown's book tracks the move into American modernism in the early twentieth century by looking at the way in which late nineteenth-century literary texts use things. Frank Norris’s McTeague; Sarah Orne Jewett's The Country of the Pointed Firs (1896); Mark Twain's The Prince and the Pauper (1881); Henry James's The Spoils of Poynton (1896) and The American Scene (1905-7) constitute his major case studies although the book is also informed by much else - including museology, anthropological theory, psychoanalytic theory, art history, philosophy, poetry, and particularly by a line of William Carlos Williams, 'No ideas but in things' which becomes a one-line manifesto for the book. 'No ideas but in things' usefully marks the methodological space between Brown's book and Freedgood's. While she is interested in the ideas that might attach themselves to things through their association with the morally dubious practices of

\section{Claire Pettitt, On Stuff}

19: Interdisciplinary Studies in the Long Nineteenth Century, 6 (2008) www.19.bbk.ac.uk 
empire or industrial production, Brown tries to discipline his study to focus only on ideas that inhere or are produced by things themselves.

Brown is also taking issue with Marx, or perhaps calling his bluff, pointing out that 'Marx's vivid portrayal of the commodity’s vivacity - the imagery with which he portrays the commodified object-come-to-life - does not quite square with his theoretical presentation of the commodity’s fetishization' ${ }^{20}$ The dancing table, standing on its head and 'evolv[ing] out of its wooden brain grotesque ideas' in the first volume of Capital is where Brown starts. He suggests that even Marx, whose arguments depend upon 'placing' things as commodities, knows that things can and do move. They move around in the sense of displacing themselves, and they 'move' us affectively: we cherish them, or we throw them away, or we ignore them. By granting things a kind of 'interiority’ or 'subjectivity’, Brown reopens Bruno Latour's argument that we should be suspicious of 'that modernity which insists on an ontological distinction, arbitrary and artificial, between inanimate objects and human subjects. ${ }^{21}$ Brown thinks about the power of the commodity to solicit human response as happens in Emile Zola's $\mathrm{Au}$ Bonheur des Dames (1883) when, in Octave Mouret's department store, 'the cloaks threw out their folds over the dummies, which assumed a soul ${ }^{22}$ or in Theodore Dreiser's Sister Carrie (1900) when gloves whisper seductively from a display case. But he also asks what happens to the commodity once it is taken home and worn or used, loved or cast off? Amanda Vickery has, through her work on the material world of Elizabeth Shackelton in eighteenth-century Yorkshire, brought out 'the multitude of meanings invested in possessions over time. ${ }^{23}$ This seems fundamental to understanding the thing-world and perhaps draws us closer to Elaine Freedgood's category of Victorian thing culture: a culture not focused on display and desire alone but also on the politics of possession.

Brown's disciplined attention to things throws new and bright light upon some of these classics of American literature - his reading of Frank Norris’s McTeague, for example, suggests that Norris's iterative insistence on habit in his characters' lives in that novel 
contrasts with the vivacity and fungibility of things in ways that illuminate that most complex of naturalism's conundrums: 'How do we understand the relation between the most basic question that formal analysis poses - a question about repetition and deviation - and those questions about biological preservation and change established by Lamark and Darwin? ${ }^{24}$ He shows how Twain uses the royal seal in The Prince and the Pauper to 'expose the difference between monarchy and democracy as an illusion': the seal, whilst being used as a nutcracker by the pauper-pretender, is no longer the seal, but a nutcracker: 'The Prince and the Pauper addresses not only the subject's production of the object (seal or nutcracker), but also the object's production of the subject (prince or pauper). ${ }^{25}$ He places Jewett's regional 'local colour' writing in The Country of the Pointed Firs in the context of late-century anthropology, museology and ethnography, and shows how she 'participates in a new "object-based" epistemology where physical things attach people to places' while she also dramatizes, he claims, the limits of such a materialist approach to identity. ${ }^{26}$ Brown's Coda, on Henry James's final novel, The American Scene, posits the idea of modernity as a 'disaster site' strewn with dispossessed objects longing for history and meaning - displaced as they are into the endless and restless present of commodity culture. Through the study of 'things' Brown is able to think afresh about the potentialities and constraints of genre, and importantly about the pressure of a rapidly changing society upon literary form. This is rigorous and scholarly work founded upon a sustained study of phenomenology, of aesthetics and of literature. It is worth noting, I think, that both Freedgood's and Brown's books have come out with the same publisher: both are very handsome and reasonably-priced volumes, and provide evidence of a lively and imaginative literary list at the University of Chicago Press.

The violence of the intrusion of the arm with the hammer and the little midshipman into Dickens's domestic space is perhaps predicated upon their lack of bodily connection to him. The other carefully preserved items, pens and snuff boxes and a pretty flowery teacup he used to drink from in Gad's Hill: these are all to some extent prosthetic extensions of the author's body. The midshipman and the arm instead are impressions 
of his mind realised in physical stuff. As William James and Theodor Adorno have both argued, and as Bill Brown discusses, it is habit that leads to the apperception of objects:

[t]his is why Adorno insists that the human contact with things is severely limited 'under the law of pure functionality'. 'Unnatural' use, uncustomary use, is what, in contrast, discloses the composition of objects. Forced to use a knife as a screwdriver, you achieve a new recognition of its thinness, its hardness, the shape and size of the handle. ${ }^{27}$

The reason that objects are invested with such singularity and power in Dickens's novels is that he has put them to 'uncustomary use' (the golden giant, the fetishmidshipman) and thus he has really seen them (and so forces us to see them too) in ways he would never see his teacup or his hall clock. The peculiar visibility and quiddity of objects in Dickens allows him to invest them with the threatening, pervasive but curiously centreless power of modernity: they allow him to make impersonality personal.

\section{Endnotes:}

${ }^{1}$ Bill Brown, A Sense of Things: The Object Matter of American Literature (Chicago: Chicago University Press, 2003).

${ }^{2}$ Charles Dickens, Dombey and Son (1846-8; repr. London: Penguin, 2002), p. 286. Further references are given in the text as DS.

${ }^{3}$ Charles Dickens, A Tale of Two Cities (1859; repr. London: Penguin, 2003), p. 95.

${ }^{4}$ Museum label at The Charles Dickens Museum, 48 Doughty Street, London, March 2008.

${ }^{5}$ Brown, p. 68.

${ }^{6}$ Charles Dickens, Great Expectations (1860-1; repr. London: Penguin, 2003), p. 159.

${ }^{7}$ Elaine Freedgood, The Idea in Things: Fugitive Meaning in the Victorian Novel (Chicago: University of Chicago Press, 2006).

${ }^{8}$ Jean Baudrillard, Fatal Strategies, trans. by Philip Beitchman and W. G. J. Niesluchowski, ed. by. Jim Fleming (New York: Semiotext(e), 1990), p. 111.

${ }^{9}$ Freedgood, p. 2

${ }^{10}$ Freedgood, p. 120.

${ }^{11}$ Freedgood, p. 8.

Claire Pettitt, On Stuff

19: Interdisciplinary Studies in the Long Nineteenth Century, 6 (2008) www.19.bbk.ac.uk 
${ }^{12}$ Freedgood, pp. 2, 14.

${ }^{13}$ Freedgood, p. 14.

${ }^{14}$ Freedgood, p. 2.

${ }^{15}$ Freedgood, p. 51.

${ }^{16}$ Freedgood, p. 51.

${ }^{17}$ Henry Mayhew, Life and Labour of the London Poor (1861-2; repr. New York: Dover Publications, 1968), p. 48.

${ }^{18}$ Carolyn Steedman, 'What a rag rug means', in Dust (Manchester: Manchester University Press, 2001), pp. 112-141.

${ }^{19}$ Steedman, p. 136.

${ }^{20}$ Brown, p. 27.

${ }^{21}$ Brown, p. 187; Bruno Latour, We Have Never Been Modern, trans. by Catherine Porter (Cambridge, MA.: Harvard University Press, 1993).

${ }^{22}$ Brown, p. 32.

${ }^{23}$ Amanda Vickery, 'Women and the World of Goods: A Lancashire Consumer and her Possessions, 1751-81', in John Brewer and Roy Porter (eds.), Consumption and the World of Goods (London and New York: Routledge, 1993), pp. 274-301 (pp. 281-2). Emphasis mine.

${ }^{24}$ Brown, p. 53.

${ }^{25}$ Brown, p. 39.

${ }^{26}$ Brown, p. 84.

${ }^{27}$ Brown, p. 78. 